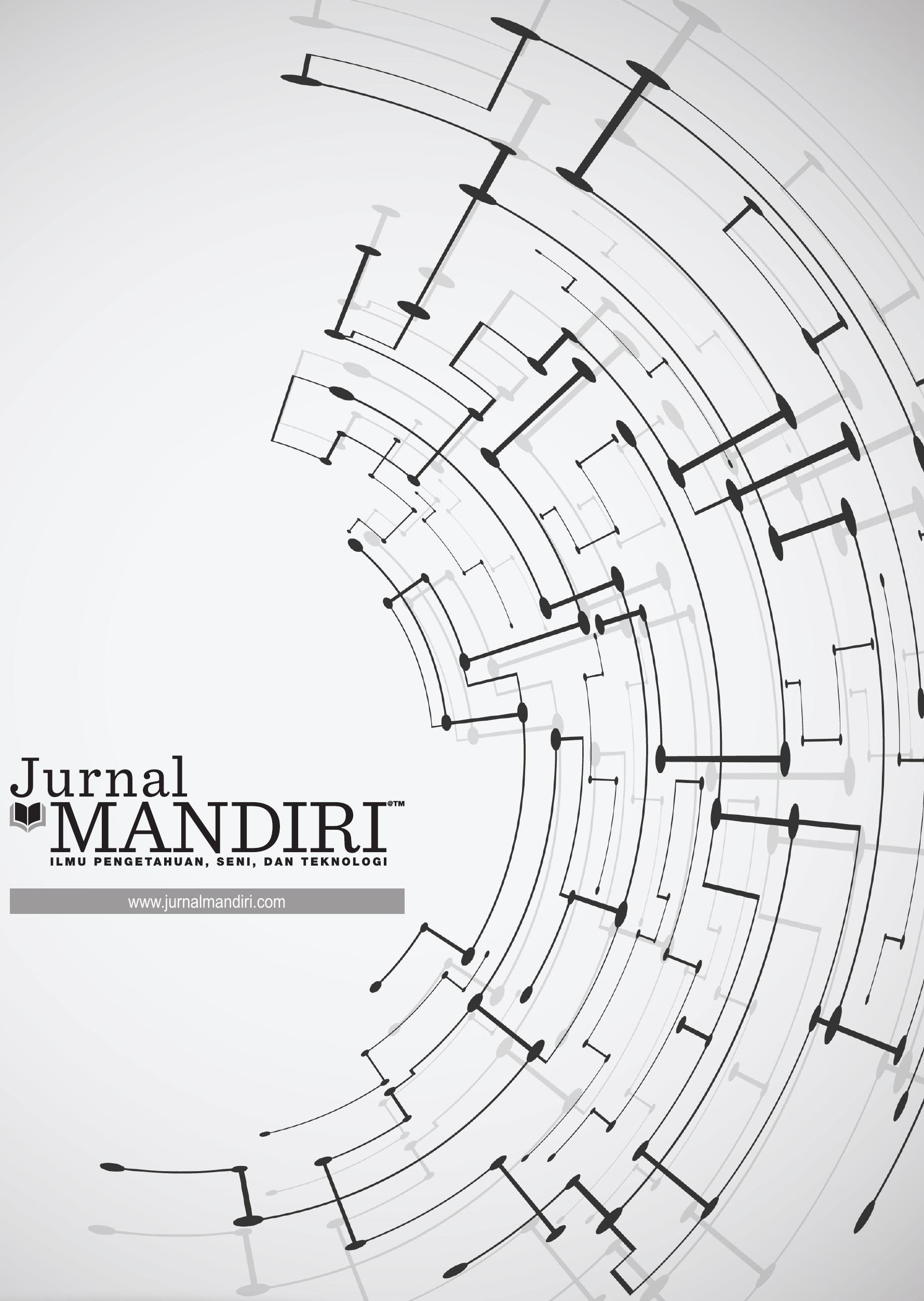


ISSN : 2580-3220, E-ISSN : 2580-4588

J. Mandiri., Vol. 4, No. 1, Juni 2020 (1 - 13)

(C)2018 Lembaga Kajian Demokrasi

dan Pemberdayaan Masyarakat (LKD-PM)

DOI : https://doi.org/10.33753/mandiri.v4i1.101

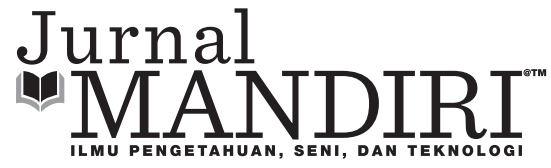

\title{
Pengaruh Kompensasi Terhadap Kinerja Karyawan Pada PT Gratia Prima Indonesia
}

\author{
Jeni Irnawati \\ Fakultas Ekonomi, Universitas Pamulang \\ dosen02228@unpam.ac.id \\ Sam Cay \\ Fakultas Ekonomi, Universitas Pamulang \\ dosen02207@unpam.ac.id
}

\begin{abstract}
Abstrak
Tujuan dari penelitian ini adalah untuk mengetahui apakah terdapat pengaruh antara kompensasi dan kinerja karyawan pada PT Gratia Prima Indonesia. Kompensasi merupakan pendapatan yang berbentuk uang, barang langsung atau tidak langsung yang diterima karyawan sebagai imbalan atas jasa yang diberikan kepada karyawan. Kompensasi merupakan salah satu hal penting dalam suatu perusahaan. Dengan adanya kompensasi, karyawan akan terdorong untuk melakukan sesuatu guna memenuhi kebutuhan hidupnya. Teknik analisis data yang dipergunakan dalam penelitian ini adalah metode deskriptif kuantitatif yaitu dengan mendeskripsikan keadaan responden serta deskripsi variabel penelitian dalam tabel frekuensi dan persentase dari hasil penyebaran angket dengan melalui prosedur analisis data yaitu wawancara, kuesioner dan observasi. Hasil penelitian menunjukkan bahwa terdapat pengaruh yang positif dan signifikan antara kompensasi terhadap kinerja karyawan pada PT Gratia Prima Indonesia dengan koefisien korelasi sebesar 0,833 berarti pengaruh kompensasi terhadap kinerja karyawan SANGAT KUAT kaitannya. Hal ini mengacu pada tabel 4.14 bahwa $(0,80-1,00)$ dinyatakan sangat kuat. Dari perhitungan koefisien determinasi diperoleh nilai sebesar 69,39\%, sedangkan sisanya $(100 \%-64,39 \%)=30,61 \%$ dipengaruhi oleh faktor lain. Dan hasil dari pengujian rumus maka $t_{\text {hitung }}>t_{\text {tabel }}$ yaitu 10,82>2,006 yang artinya $H_{0}$ ditolak dan $H_{a}$ diterima, artinya Pengaruh Kompensasi (X) mempunyai Pengaruh yang signifikan terhadap Kinerja Karyawan (Y). Karena hasil yang diperoleh menyatakan bahwa terdapat pengaruh yang positif dan signifikan antara kompensasi terhadap kinerja karyawan maka hasil ini dapat memberikan masukan atau informasi kepada PT Gratia Prima Indonesia.
\end{abstract}

Kata Kunci : Kompensasi, Kinerja Karyawan

\begin{abstract}
The purpose of this study is to determine whether there is an influence between compensation and employee performance at PT Gratia Prima Indonesia. Compensation is income in the form of money, direct or indirect goods received by employees in return for services rendered to employees. Compensation is one of the important things in a company. With compensation, employees will be compelled to do something to meet their needs. The data analysis technique used in this research is quantitative descriptive method by describing the condition of the respondent as well as the description of the research variables in the frequency and percentage tables of the results of questionnaire distribution through data analysis procedures, namely interviews, questionnaires and observations. The results showed that there was a positive and significant effect between compensation on employee performance at PT Gratia Prima Indonesia with a correlation coefficient of 0.833 meaning the effect
\end{abstract}


of compensation on employee performance was STRONGLY related. This refers to table 4.14 that (0.80-1.00) is stated to be very strong. From the calculation of the coefficient of determination obtained a value of $69.39 \%$, while the rest $(100 \%-64.39 \%)=30.61 \%$ is influenced by other factors. And the results of the formula test then $t_{\text {count }}>t_{\text {table }}$ is 10.82> 2.006 which means $H_{0}$ is rejected and $H_{a}$ is accepted, meaning that the Compensation Effect $(X)$ has a significant effect on Employee Performance ( $Y)$. Because the results obtained state that there is a positive and significant effect between compensation on employee performance, these results can provide input or information to PT Gratia Prima Indonesia.

Keywords : Motivation, Employee Performance

\section{PENDAHULUAN}

\section{Latar Belakang}

Ketika datang ke kondisi ekonomi, politik dan sosial yang sangat cepat dan sulit diprediksi pada saat ini, organisasi benar-benar membutuhkan konsolidasi internal yang kuat dan dapat meningkatkan ketahanan mereka dan dapat memastikan pencapaian misi dan visi organisasi yang ada. Kegagalan organisasi untuk mengantisipasi perubahan dapat membuat organisasi tidak berkelanjutan. Sebagai sistem organisasi, kehidupan perusahaan sangat dipengaruhi oleh faktor lingkungan internal (di dalam perusahaan) dan eksternal (di luar perusahaan).

Faktor lingkungan dipengaruhi dari jalannya roda organisasi yang berubah. Dalam hal ini, perusahaan sebagai organisasi harus selalu beradaptasi dan memenuhi tuntutan lingkungan. Beradaptasi pada lingkungan mempunyai arti bahwa perusahaan bisa memanfaatkan peluang yang ada untuk dapat mengatasi ancaman dimasa mendatang, mengoptimalkan kekuatan, dan menghilangkan kelemahan yang ada. Oleh karena itu, dilakukanlah berbagai kegiatan perusahaan dalam beradaptasi dengan lingkungan karena perubahan dinamika yang ada.

Tekanan kompetitif dalam dunia bisnis juga mengharuskan perusahaan untuk memikirkan bagaimana perusahaan harus mengatasi dan bahkan menghadapi perubahan lingkungan. Satusatunya yang memenuhi persyaratan adalah lingkungan organisasi, salah satu kegiatan yang harus dimunculkan setelah pelatihan dan pengembangan karyawan. Salah satu aspek terpenting dalam suatu organisasi adalah pengembangan dan pengelolaan sumber daya manusia ini. Sumber daya manusia adalah salah satu aset perusahaan yang memainkan peran penting karena tanpa sumber daya manusia mereka bekerja secara efektif dan efisien.

Kebijakan yang diterapkan terutama dalam pemberian kompensasi dimaksudkan untuk meningkatkan kinerja karyawan sesuai dengan hasil yang ingin dicapai. Perusahaan yang berhasil memotivasi karyawannya dapat menciptakan kekuatan untuk mencapai kinerja yang efektif. Kompensasi proporsional baik finansial maupun non finansial harus menjadi perhatian utama manajemen masing-masing perusahaan karena kompensasi akan memotivasi karyawan untuk meningkatkan kinerja sejalan dengan kepatuhan terhadap kesejahteraan karyawan. Oleh karena itu, kompensasi sangat penting bagi karyawan itu sendiri sebagai individu, karena jumlah kompensasi adalah cerminan atau ukuran nilai tenaga kerja karyawan. Sebaliknya, ukuran offset dapat memengaruhi kinerja. Jika kompensasi diberikan dengan benar dan benar, karyawan dapat meningkatkan kinerja mereka untuk mencapai tujuan organisasi. Namun, jika kompensasi tidak memadai atau tidak memadai, karyawan tidak akan termotivasi dan tujuan organisasi tidak akan tercapai karena kinerja karyawan yang lebih rendah dan optimal.

Books \& Beyond ("B\&B") yang sebelumnya dikenal sebagai Times Bookstore, dikelola oleh PT Gratia Prima Indonesia, yang merupakan unit bisnis PT. Multi Polar.Tbk Perusahaan ritel multiformat lokal terkemuka di Indonesia. Toko buku Times pertama kali dibuka pada 2008 dengan toko pertama di UPH, Lippo Karawaci, Tangerang. Sejak 10 Oktober 2012, toko buku Times telah mengubah namanya menjadi Books \& Beyonds. Books \& Beyond menawarkan buku, majalah, 
alat tulis, permainan edukasi, hadiah, elektronik dan kebutuhan gaya hidup yang beragam. Book \& Beyond adalah toko buku pertama berbahasa Inggris di Indonesia. Menyediakan berbagai layanan buat pelanggan termasuk menyediakan pelayanan pesan pelanggan. Saat ini Books \& Beyond ini sudah memiliki 40 titik penjualan yang tersebar di JABODETABEK, Palembang, Manado, Bandung, Medan, Bali, Balikpapan, Makassar, dan akan terus tumbuh untuk memenuhi kebutuhan pembaca di Indonesia.

Visi PT.Gratia Prima Indonesia: 1) Untuk menjadi toko buku terkemuka di Indonesia, memenuhi kebutuhan pembaca dengan dedikasi dan profesional;2) Menjadirantaitokobukuterkemuka di Indonesia dan memberikan pengalaman berbelanja buku yang disukai di Negara yang sedang tumbuh minat membaca; 3) Berkontribusi untuk pembangunan bangsa melalui pendidikan, melayani pembaca dengan pendekatan personal karena kami terus mengembangkan hubungan yang kuat dan mendukung penerbit.

Misi PT.Gratia Prima Indonesia: 1) Untuk mengembangkan gairah yang lebih besar di masyarakat melalui kegiatan membaca dan menulis, dan meningkatkan cinta membaca dan tingkat pendidikan di kepulauan Indonesia; 2) Memberikan kontribusi perkembangan dan pertumbuhan intelektual bangsa lebih dari 250 juta warga.

Menurut Malayu S.P Hasibun (2009: 10) "Manajemen sumber daya manusia adalah ilmu dan seni mengatur hubungan dan peran tenaga kerja agar efektif dan efisien membantu terwujudnya tujuan perusahaan, karyawan dan masyarakat". Lebih jauh Malayu S.P. Hasibun (2009: 11) mengatakan, "Personal Management may be defined as the process developing, applying and evaluating policies, procedures, methods, and programs relating individual in the organization". Yang artinya Manajemen personalia sebagai suatu proses pengembangan, penerapan dan evaluasi kebijakan, prosedur, metode, dan program yang berkaitan dengan masing-masing karyawan dalam organisasi.

\section{METODE}

Metode penelitian merupakan cara ilmiah untuk mendapatkan data dengan tujuan dan kegunaan tertentu. Menurut Sugiono (2008: 4) metode penelitian adalah cara ilmiah untuk memperoleh data yang valid dengan tujuan ditemukan, diuji, mengembangkan pengetahuan tertentu sehingga pada gilirannya dapat digunakan untuk memahami, memecahkan, dan mengantisipasi masalah.

Jenis penelitian yang digunakan dalam penelitian ini dalah penelitian asosiatif kausal dengan pendekatan kuantitatif. Pendekatan asosiatif dilakukan untuk menjawab persoalanpersoalan tentang fenomena-fenomena yang berlaku sekarang, serta menganalisis pengaruh antara dua variabel atau lebih dalam fenomena tersebut.

Menurut Sugiono (2008: 11) "menyatakaan bahwa penelitian asosiatif merupakan penelitian yang bertujuan untuk mengetahui pengaruh antara dua variabel atau lebih. Dengan penelitian ini akan dapat dibangun suatu teori yang dapat berfungsi untuk menjelaskan, meramalkan dan mengontrol suatu gejala".

Pendekatan kuantitatif menurut Umar (2002: 95) adalah "pendekatan yang didasarkan pada data yang dihitung untuk menghasilkan penafsiran yang kokoh". Dalam penelitian ini menghubungkan kompensasi sebagai variabel bebas dan kinerja karyawan sebagai variabel terikat pada PT Gratia Prima Indonesia.

\section{Populasi dan Sampel}

Menurut Sugiyono (2013: 148), "Populasi adalah wilayah generalisasi yang terdiri atas obyek atau subyek yang mempunyai kuantitas dan karakteristik tertentu yang ditetapkan oleh peneliti untuk mempelajari dan kemudian ditarik kesimpulannya”. Berdasarkan pada tempat penelitian yang telah ditentukan, maka populasi yang dijadikan objek dalam penelitian ini adalah seluruh karyawan pada karyawan PT Gratia Prima Indonesia yang berjumlah 120 karyawan dan dihitung menggunakan rumus slovin dengan tarif kesukaran 5\% maka diperoleh sampel sebanyak 55 karyawan. 
Metode analisis adalah metode yang digunakan untuk memproses data. Pemrosesan data ini sangat penting agar data yang telah terkumpul dapat dianalisis dan kemudian diberi makna yang berguna dalam menyelesaikan masalah penelitian.

Untuk mengumpulkan data tentang variabel independen (X) yaitu remunerasi atau kompensasi dan variabel dependen $(\mathrm{Y})$ yaitu kinerja karyawan, kuesioner digunakan untuk 55 responden yang semuanya adalah karyawan PT. Gratia Prima Indonesia. Kuesioner terdiri dari 15 pernyataan, di mana setiap jawaban mengacu pada skala.

\begin{tabular}{|c|c|}
\hline \multicolumn{2}{|c|}{ Tabel 1. Kategori Skor Penilaian (Skala likert) } \\
\hline Alternatif Pilihan Jawaban Pernyataan & Skor Jawaban \\
\hline Sangat Setuju & 5 \\
\hline Setuju & 4 \\
\hline Ragu-ragu & 3 \\
\hline Tidak Setuju & 2 \\
\hline Sangat Tidak Setuju & 1 \\
\hline
\end{tabular}

Metode analisa data yang digunakan adalah Uji Validitas. Validitas berarti instrumen yang digunakan untuk mengukur apa yang harus diukur. Tes ini berfungsi untuk menunjukan kemampuan alat pengukur untuk dapat memberikan apa tujuan pengukuran utama. Tes validitas ini digunakan untuk mengukur sah atau valid kuesioner. Sebuah kuesioner dikatakan valid jika pertanyaan pada kuesioner dapat mengungkapkan sesuatu yang akan diukur oleh kuesioner.

Uji Reabilitas berarti instrumen yang jika digunakan beberapa kali untuk mengukur objek yang sama, akan menghasilkan data yang sama. Reliabilitas adalah alat pengukuran untuk mengukur kuesioner yang merupakan indikator variabel. Tujuan dari tes ini adalah agar data yang dikumpulkan benar-benar andal, konsisten dan dapat diandalkan. Metode yang digunakan dalam penelitian ini untuk menghitung reabilitas instrumen adalah dengan menggunakan metode Alpha Cronbach. Suatu variabel dikatakan reliabel jika memberikan nilai $\alpha>0.60$.

Koefisien Korelasi, untuk memberikan interpretasi dari koefisien korelasi yang ditemukan besar atau kecil, dapat disimpulkan dalam ketentuan untuk memberikan interpretasi dari koefisien korelasi yang dapat dilihat pada tabel di bawah ini menurut Sugiyono (2013: 287).

Berikut adalah pedoman untuk memberikan interpretasi koefisien korelasi:

\begin{tabular}{|c|c|c|}
\hline \multicolumn{3}{|c|}{ Tabel 2. Interpretasi Koefisien Korelasi } \\
\hline No & Interval Koefisien & \begin{tabular}{c} 
Tingkat Hubungan \\
\hline 1
\end{tabular} \\
\hline 2 & $0,00-0,199$ & Sangat Rendah \\
\hline 3 & $0,20-0,399$ & Rendah \\
\hline 4 & $0,40-0,599$ & Cukup Kuat \\
\hline 5 & $0,60-0,799$ & Kuat \\
\hline \multicolumn{2}{|c}{} & Sangat Kuat \\
\hline
\end{tabular}

Setelah dianalisa korelasi dilakukan, maka selanjutnya akan dihitung besarnya koefisien determinasi.

Rumus:

Keterangan:

$\mathrm{KD}=$ Koefisien Determinasi

$\mathrm{r}=$ Koefisien Korelasi

Dan untuk menguji signifikan hubungan antara pengaruh kompensasi terhadap kinerja karyawan, maka perlu suatu pengujian signifikan dengan rumus berikut :

Rumus :

$\mathrm{KD}=\mathrm{r}^{2} \times 100 \%$

Di mana :

$\mathrm{n}=$ jumlah sampel

$\mathrm{t}=\mathrm{t}_{\text {hitung }}$ yang selanjutnya dikonsultasikan dengan $t_{\text {tabel }}$

$\mathrm{r}=$ koefisien korelasi

dengan menggunakan uji searah atas makna kriteria uji yaitu :

a. Jika $\mathrm{t}_{\text {hitung }}<\mathrm{t}_{\text {tabel }}$ berarti $\mathrm{H}_{0}$ diterima

b. Jika $\mathrm{t}_{\text {hitung }}>\mathrm{t}_{\text {tabel }}$ berarti $\mathrm{H}_{0}$ ditolak Interprestasi taraf signifikan :

a. Apabila $\mathrm{t}_{\text {hitung }}>\mathrm{t}_{\text {tabel }}$ pada taraf signifikan $5 \%$ berarti hubungan antara variabel sangat signifikan.

b. Apabila $\mathrm{t}_{\text {hitung }}<\mathrm{t}_{\text {tabel }}$ pada taraf signifikan $5 \%$ berarti hubungan antara variabel tidak signifikan. 
Hipotesis :

$\mathrm{H}_{0}$ : koefisien korelasi tidak signifikan

$\mathrm{H}_{\mathrm{a}}$ : koefisien korelasi signifikan

Pengujian ini menggunakan hipotesis:

Pengaruh Kompensasi terhadap Kinerja Karyawan

$\mathrm{H}_{0}$ : Tidak ada pengaruh secara signifikan antara variabel bebas (kompensasi) terhadap variabel terikat (Kinerja Karyawan) dimana $\beta \mathrm{i}=0$

$\mathrm{H}_{\mathrm{a}}$ : Ada pengaruh secara signifikan antara variabel bebas (kompensasi) terhadap variabel terikat. Jadi metode analisa yang digunakan dalam penilitian ini adalah Uji Validitas, Uji Realibilitas, Koefisien korelasi, koefisien Determinasi, Regresi Linier sederhana, Uji Signifikansi dan Uji Hipotesis.

\section{HASIL dan PEMBAHASAN Pengertian Kompensasi}

Kompensasi adalah cara untuk meningkatkan kepuasan kerja karyawan dan kinerja karyawan. Kompensasi adalah satu hal yang sangat penting bagi karyawan sebagai individu, karena jumlah kompensasi yang diberikan adalah ukuran keberhasilan bagi individu tersebut. Jika kompensasi diberikan dengan benar, itu akan mempengaruhi perilaku karyawan untuk mencapai tujuan organisasi.

Henry Simamora (2004: 442) mendefinisikan "Kompensasi meliputi imbalan finansial dan jasa nirwujud serta tunjangan yang diterima oleh karyawan sebagai bagian dari hubungan kepegawaian". kompensasi merupakan apa yang diterima oleh karyawan sebagai ganti kontribusi mereka kepada organisasi. Lebih jauh Henry Simamora (2004: 461) mengatakan "ada dua pertimbangan kunci dalam sistem pemberian kompensasi yang efektif. Pertama, sistem kompensasi harus adaptif terhadap situasi. Sistem harus sesuai dengan lingkungan dan mempertimbangkan tujuan, sumber daya, dan struktur organisasi. Kedua, sistem kompensasi harus memotivasi para pegawai. Sistem harus bisa memuaskan kebutuhan pegawai, memastikan adanya perlakuan adil terhadap pegawai dan memberikan imbalan terhadap kinerja karyawan".

Henry Simamora membedakan kompensasi menjadi dua jenis, yaitu kompensasi langsung dan kompensasi tidak langsung. Kompensasi dapat berarti semua pendapatan dalam bentuk uang, barang langsung atau tidak langsung yang diterima oleh karyawan sebagai kompensasi atau layanan diberikan kepada perusahaan. Kompensasi dalam bentuk uang berarti kompensasi dibayarkan dalam mata uang kepada karyawan yang bersangkutan. Kompensasi dalam bentuk aset berarti kompensasi dibayarkan dari aset. Kompensasi dapat dibagi menjadi dua, yaitu Kompensasi langsung (direct compensation) dalam bentuk gaji, upah dan pembayaran insentif; kompensasi tidak langsung (inderect compensation atau employee welfare) kesejahteraan karyawan.

Tujuan pemberian kompensasi (remunerasi) meliputi kerjasama, kepuasan kerja, perekrutan yang efektif, motivasi, stabilitas karyawan, disiplin, dan pengaruh serikat pekerja dan pemerintah. Dengan kata lain, pemberian remunerasi harus memuaskan semua pihak, karyawan dapat memenuhi kebutuhan mereka, pengusaha mendapat untung, peraturan pemerintah harus dipatuhi, dan konsumen mendapatkan produk yang bagus dengan harga yang wajar.

\section{Kinerja}

Menurut Anwar Prabu Mangkunegara (2007: 67) "kinerja (prestasi kerja) adalah hasil kerja secara kualitas dan kuantitas yang dicapai oleh seorang dalam melaksanakan sesuai dengan tanggung jawab yang diberikan kepadanya". Sedangkan Menurut Rivai dan Basri (2005) "kinerja adalah kesediaan seseorang atau kelompok orang untuk melakukan suatu kegiatan dan menyempurnakannya sesuai dengan tanggung jawab dengan hasil yang seperti yang diharapkan".

Sederhananya, kinerja didefinisikan sebagai hasil yang dicapai oleh seorang karyawan selama periode waktu tertentu dalam bidang pekerjaan tertentu. Seseorang yang memiliki kinerja tinggi dan baik dapat mendukung pencapaian tujuan dan 
sasaran yang ditetapkan oleh perusahaan. Agar memiliki pekerjaan yang tinggi dan baik, seorang karyawan dalam melaksanakan pekerjaannya harus memiliki pengalaman dan keterampilan sesuai dengan pekerjaan yang dimilikinya.

Tujuan penilaian kinerja dapat berorientasi pada nilai, sanksi, dan lebih fokus pada penempatan karyawan pada posisi tertentu, tetapi juga pada mengantisipasi pengembangan karyawan dalam melakukan posisi mereka untuk meningkatkan sumber daya manusia di masa depan.

Selain itu Veithzal Rivai (2006: 313) menetapkan tujuan evaluasi kinerja sebagai berikut: 1) Tujuan evaluasi berorientasi masa lalu. Dalam praktiknya masih banyak perusahaan yang menerapkan evaluasi kinerja berorientasi masa lampau, hal ini disebabkan oleh kurangnya pemahaman tentang manfaat evaluasi kinerja sebagai sarana untuk mengungkap potensi karyawan salah satunya adalah mencari karyawan untuk melakukan pekerjaan tertentu. 2) Tujuan evaluasi masa depan, jika dirancang dengan baik, sistem evaluasi ini dapat membantu setiap karyawan untuk lebih memahami peran mereka dan memahami fungsi merke dengan jelas, dan merupakan alat untuk membantu setiap karyawan memahami kekuatan dan kelemahan yang terkait dengan peran dan fungsi dalam perusahaan.

Kemampuan karyawan untuk melakukan sesuatu yang aman. Kinerja karyawan sangat diperlukan, karena dengan kinerja ini Anda akan tahu sejauh mana kemampuan Anda untuk melaksanakan tugas yang diberikan kepada Anda. Untuk alasan ini, perlu menetapkan kriteria yang jelas dan terukur, dan menetapkannya bersama untuk digunakan sebagai referensi. Jika Anda melihat etologi, kinerja berasal dari kata performance.

\section{Deskripsi Data}

Berikut ini penulis sajikan data karakteristik responden berdasarkan jenis kelamin responden, usia responden, pendidikan responden dan lama kerja responden pada PT. Gratia Prima Indonesia.

\begin{tabular}{|c|c|c|}
\hline \multicolumn{2}{|c|}{ Tabel 3. Responden Berdasarkan Jenis Kelamin } \\
\hline Jenis Kelamin & Frekuensi & Persentase (\%) \\
\hline Laki-laki & 31 & $56,4 \%$ \\
\hline Perempuan & 24 & $43,6 \%$ \\
\hline Jumlah & 55 & $\mathbf{1 0 0 \%}$ \\
\hline \multicolumn{2}{|c|}{ Sumber: Data Olahan Kuesioner } \\
\hline
\end{tabular}

\begin{tabular}{|c|c|c|}
\hline \multicolumn{3}{|c|}{ Tabel 4. Responden Berdasarkan Usia } \\
\hline Usia & Frekuensi & Persentase $(\%)$ \\
\hline $18-28$ tahun & 29 & $52,7 \%$ \\
\hline $29-39$ tahun & 21 & $38,2 \%$ \\
\hline $40-50$ tahun & 5 & $9.1 \%$ \\
\hline Jumlah & $\mathbf{5 5}$ & $\mathbf{1 0 0 \%}$ \\
\hline \multicolumn{2}{|c}{} \\
\hline
\end{tabular}

Tabel 5. Responden Berdasarkan Pendidikan

\begin{tabular}{|c|c|c|}
\hline Usia & Frekuensi & Persentase (\%) \\
\hline SMP & 6 & $10,9 \%$ \\
\hline SMU & 28 & $50,9 \%$ \\
\hline D3 & 9 & $16,4 \%$ \\
\hline S1 & 12 & $21,8 \%$ \\
\hline Jumlah & 55 & $100 \%$ \\
\hline \multicolumn{2}{|c|}{ Sumber: Data Olahan Kuesioner, 2014 } \\
\hline
\end{tabular}

\section{Tabel 6. Responden Berdasarkan Lama Kerja}

\begin{tabular}{|c|c|c|}
\hline Lama Kerja & Frekuensi & Persentase (\%) \\
\hline$<5$ tahun & 35 & $63,6 \%$ \\
\hline $6-10$ tahun & 12 & $21,8 \%$ \\
\hline $11-15$ tahun & 8 & $14,6 \%$ \\
\hline Jumlah & 55 & $100 \%$ \\
\hline \multicolumn{2}{|c|}{ Sumber: Data Olahan Kuesioner, 2014} \\
\hline
\end{tabular}

\section{Hasil Uji Validitas}

\section{Uji Validitas Variabel X (Kompensasi)}

Uji validitas digunakan untuk mengevaluasi pernyataan ataupun pertanyaan dalam kuesioner yang didistribusikan, apakah valid atau tidak. Untuk menentukan apakah data yang diperoleh dari hasil penelitian dapat digunakan atau tidak, penulis menggunakan uji validitas.

Langkah untuk menguji validitas pernyataan dalam kuesioner pada penelitian ini dapat disajikan sebagai berikut dengan menggunakan rumus product moment :

$$
r_{x y}=\frac{n\left(\sum X Y\right)-\left(\sum X\right)\left(\sum Y\right)}{\sqrt{\left[n\left(\sum X^{2}\right)-\left(\sum X\right)^{2} \mid n\left(\sum Y^{2}\right)-\left(\sum Y\right)^{2}\right.}}
$$

Perhitungan membandingkan nilai $\mathrm{r}_{\text {hitung }}$ dengan $\mathrm{r}_{\text {tabel }}$ dengan tingkat signifikan (kesalahan) $5 \%$. Jika hasilnya positif dan lebih besar dari $\mathrm{r}_{\text {tabel' }}$ 
pernyataan atau pertanyaan dikatakan valid. Berikut ini adalah hasil perhitungan uji validitas variabel kompensasi (X).

\begin{tabular}{|c|c|c|c|}
\hline $\begin{array}{c}\text { No } \\
\text { Pertanyaan }\end{array}$ & $r$ hitung & $r$ tabel & Keterangan \\
\hline 1 & 0,414 & 0,266 & Valid \\
\hline 2 & 0,479 & 0,266 & Valid \\
\hline 3 & 0,435 & 0,266 & Valid \\
\hline 4 & 0,706 & 0,266 & Valid \\
\hline 5 & 0,705 & 0,266 & Valid \\
\hline 6 & 0,642 & 0,266 & Valid \\
\hline 7 & 0,780 & 0,266 & Valid \\
\hline 8 & 0,725 & 0,266 & Valid \\
\hline 9 & 0,732 & 0,266 & Valid \\
\hline 10 & 0,603 & 0,266 & Valid \\
\hline 11 & 0,781 & 0,266 & Valid \\
\hline 12 & 0,726 & 0,266 & Valid \\
\hline 13 & 0,732 & 0,266 & Valid \\
\hline 14 & 0,732 & 0,266 & Valid \\
\hline 15 & 0,674 & 0,266 & Valid \\
\hline
\end{tabular}

Dari tabel sebelumnya dapat dilihat bahwa dari nilai global koefisien korelasi $\left(\mathrm{r}_{\text {hitung }}\right)$ memiliki nilai lebih besar dari rtabel. Dapat disimpulkan bahwa lima belas elemen dari deklarasi ini valid karena positif dan lebih besar dari rtabel untuk $\mathrm{n}=55$, yang sama dengan 0,266 . Elemen dengan validitas tertinggi adalah elemen kedua belas yang sama dengan 0,781 dan validitas terendah adalah elemen kedua yaitu 0,414 .

Berikut ini adalah contoh bukti validitas item nomor satu dari kuesioner variabel komunikasi :

Tabel 8. Perhitungan Uji Validitas

Butir Pernyataan No. 1 Variabel X (Kompensasi)

\begin{tabular}{|c|c|c|c|c|c|}
\hline No & $\mathbf{X}$ & $\mathbf{Y}$ & $\mathbf{X}^{\mathbf{2}}$ & $\mathbf{Y}^{\mathbf{2}}$ & $\mathbf{X Y}$ \\
\hline 1 & 5 & 72 & 25 & 5184 & 360 \\
\hline 2 & 5 & 73 & 25 & 5329 & 365 \\
\hline 3 & 5 & 73 & 25 & 5329 & 365 \\
\hline 4 & 4 & 56 & 16 & 3136 & 224 \\
\hline 5 & 5 & 60 & 25 & 3600 & 300 \\
\hline 6 & 5 & 59 & 25 & 3481 & 295 \\
\hline 7 & 5 & 68 & 25 & 4624 & 340 \\
\hline 8 & 5 & 62 & 25 & 3844 & 310 \\
\hline 9 & 4 & 64 & 16 & 4096 & 256 \\
\hline 10 & 4 & 64 & 16 & 4096 & 256 \\
\hline 11 & 5 & 60 & 25 & 3600 & 300 \\
\hline 12 & 5 & 75 & 25 & 5625 & 375 \\
\hline 13 & 5 & 53 & 25 & 2809 & 265 \\
\hline 14 & 4 & 60 & 16 & 3600 & 240 \\
\hline 15 & 5 & 69 & 25 & 4761 & 345 \\
\hline 16 & 5 & 61 & 25 & 3721 & 305 \\
\hline
\end{tabular}

\begin{tabular}{|c|c|c|c|c|c|}
\hline 17 & 5 & 57 & 25 & 3249 & 285 \\
\hline 18 & 5 & 68 & 25 & 4624 & 340 \\
\hline 19 & 5 & 57 & 25 & 3249 & 285 \\
\hline 20 & 5 & 74 & 25 & 5476 & 370 \\
\hline 21 & 5 & 65 & 25 & 4225 & 325 \\
\hline 22 & 4 & 61 & 16 & 3721 & 244 \\
\hline 23 & 4 & 64 & 16 & 4096 & 256 \\
\hline 24 & 4 & 60 & 16 & 3600 & 240 \\
\hline 25 & 4 & 66 & 16 & 4356 & 264 \\
\hline 26 & 5 & 68 & 25 & 4624 & 340 \\
\hline 27 & 5 & 66 & 25 & 4356 & 330 \\
\hline 28 & 5 & 75 & 25 & 5625 & 375 \\
\hline 29 & 5 & 75 & 25 & 5625 & 375 \\
\hline 30 & 5 & 75 & 25 & 5625 & 375 \\
\hline 31 & 4 & 64 & 16 & 4096 & 256 \\
\hline 32 & 5 & 75 & 25 & 5625 & 375 \\
\hline 33 & 5 & 69 & 25 & 4761 & 345 \\
\hline 34 & 5 & 69 & 25 & 4761 & 345 \\
\hline 35 & 5 & 69 & 25 & 4761 & 345 \\
\hline 36 & 5 & 71 & 25 & 5041 & 355 \\
\hline 37 & 5 & 72 & 25 & 5184 & 360 \\
\hline 38 & 5 & 72 & 25 & 5184 & 360 \\
\hline 39 & 5 & 69 & 25 & 4761 & 345 \\
\hline 40 & 4 & 65 & 16 & 4225 & 260 \\
\hline 41 & 5 & 62 & 25 & 3844 & 310 \\
\hline 42 & 5 & 71 & 25 & 5041 & 355 \\
\hline 43 & 5 & 72 & 25 & 5184 & 360 \\
\hline 44 & 5 & 72 & 25 & 5184 & 360 \\
\hline 45 & 5 & 71 & 25 & 5041 & 355 \\
\hline 46 & 5 & 61 & 25 & 3721 & 305 \\
\hline 47 & 4 & 61 & 16 & 3721 & 244 \\
\hline 48 & 4 & 64 & 16 & 4096 & 256 \\
\hline 49 & 5 & 69 & 25 & 4761 & 345 \\
\hline 50 & 4 & 65 & 16 & 4225 & 260 \\
\hline 51 & 5 & 73 & 25 & 5329 & 365 \\
\hline 52 & 5 & 73 & 25 & 5329 & 365 \\
\hline 53 & 4 & 60 & 16 & 3600 & 240 \\
\hline 54 & 5 & 60 & 25 & 3600 & 300 \\
\hline 55 & 5 & 70 & 25 & 4900 & 350 \\
\hline Jumlah & 261 & 3659 & 1249 & 245261 & 17421 \\
\hline
\end{tabular}

Sumber : Data yang telah diolah

$$
r_{x y}=\frac{n\left(\sum X Y\right)-\left(\sum X\right)\left(\sum Y\right)}{\sqrt{\left[n\left(\sum X^{2}\right)-\left(\sum X\right)^{2} \mid n\left(\sum Y^{2}\right)-\left(\sum Y\right)^{2}\right]}}
$$

$r x y=\frac{55(17421)-(261)(3659)}{\sqrt{\left[55(1249)-(261)^{2}\right]\left[55(245261)-(3659)^{2}\right]}}$

$958155-954216$

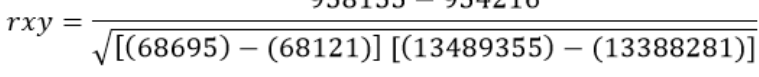

$r x y=\frac{3939}{\sqrt{(574)(101074)}}$ 
$r x y=\frac{3939}{7616,85}$

$r x y=0,517$

Keterangan : maka $\mathrm{r}_{\text {hitung }}>\mathrm{r}_{\text {tabel }}$ atau 0,517 > 0,266 dengan ketentuan $\alpha=5 \%$ dengan besar $\mathrm{r}_{\text {tabel }}=0,266$ maka variabel kompensasi $(\mathrm{X})$ dapat dikatakan valid.

\section{Hasil Uji Variabel Y (Kinerja)}

\begin{tabular}{l}
\hline \multicolumn{4}{|c|}{ Tabel 9. Validitas Instrumen Y (Kinerja) } \\
\begin{tabular}{|c|c|c|c|}
\hline $\begin{array}{c}\text { No } \\
\text { Pernyataan }\end{array}$ & r hitung & r tabel & Keterangan \\
\hline 1 & 0,673 & 0,266 & Valid \\
\hline 2 & 0,666 & 0,266 & Valid \\
\hline 3 & 0,701 & 0,266 & Valid \\
\hline 4 & 0,684 & 0,266 & Valid \\
\hline 5 & 0,622 & 0,266 & Valid \\
\hline 6 & 0,703 & 0,266 & Valid \\
\hline 7 & 0,730 & 0,266 & Valid \\
\hline 8 & 0,586 & 0,266 & Valid \\
\hline 9 & 0,778 & 0,266 & Valid \\
\hline 10 & 0,789 & 0,266 & Valid \\
\hline 11 & 0,800 & 0,266 & Valid \\
\hline 12 & 0,880 & 0,266 & Valid \\
\hline 13 & 0,842 & 0,266 & Valid \\
\hline 14 & 0,846 & 0,266 & Valid \\
\hline 15 & 0,704 & 0,266 & Valid \\
\hline & & & Sumber: Data yang Diolah \\
\hline
\end{tabular}
\end{tabular}

Dari tabel sebelumnya dapat dilihat bahwa dari nilai global koefisien korelasi (rhount) memiliki nilai lebih besar dari $\mathrm{r}_{\text {tabel }}$ Dapat disimpulkan bahwa lima belas elemen dari deklarasi ini valid karena nilai hitung $r$ adalah positif dan lebih besar dari $\mathrm{r}_{\text {tabel }}$ untuk $\mathrm{n}=55$, yang sama dengan 0,266 . Elemen dengan validitas tertinggi adalah elemen kedua belas yang sama dengan 0,880 dan validitas terendah adalah elemen kedelapan yaitu 0,586 .

Berikut ini salah satu contoh pengujian validitas terhadap butir persetujuan satu dari kuesioner variabel kinerja:

\begin{tabular}{c|c|c|c|c|c|}
\hline \multicolumn{7}{c}{ Tabel 10. Perhitungan Uji Validitas } \\
\multicolumn{1}{c|}{ Butir Pernyataan No. 1 Variabel Y (Kinerja) } \\
\hline No & $\mathbf{X}$ & $\mathbf{Y}$ & $\mathbf{X}^{2}$ & $\mathbf{Y}^{2}$ & XY \\
\hline 1 & 5 & 73 & 25 & 5329 & 365 \\
\hline 2 & 5 & 73 & 25 & 5329 & 365 \\
\hline 3 & 4 & 72 & 16 & 5184 & 288 \\
\hline 4 & 4 & 59 & 16 & 3481 & 236 \\
\hline 5 & 4 & 67 & 16 & 4489 & 268 \\
\hline
\end{tabular}

\begin{tabular}{|c|c|c|c|c|c|}
\hline 6 & 3 & 56 & 9 & 3136 & 168 \\
\hline 7 & 4 & 65 & 16 & 4225 & 260 \\
\hline 8 & 4 & 62 & 16 & 3844 & 248 \\
\hline 9 & 5 & 63 & 25 & 3969 & 315 \\
\hline 10 & 5 & 62 & 25 & 3844 & 310 \\
\hline 11 & 4 & 58 & 16 & 3364 & 232 \\
\hline 12 & 4 & 60 & 16 & 3600 & 240 \\
\hline 13 & 4 & 46 & 16 & 2116 & 184 \\
\hline 14 & 4 & 60 & 16 & 3600 & 240 \\
\hline 15 & 4 & 65 & 16 & 4225 & 260 \\
\hline 16 & 4 & 62 & 16 & 3844 & 248 \\
\hline 17 & 4 & 56 & 16 & 3136 & 224 \\
\hline 18 & 4 & 66 & 16 & 4356 & 264 \\
\hline 19 & 3 & 57 & 9 & 3249 & 171 \\
\hline 20 & 5 & 75 & 25 & 5625 & 375 \\
\hline 21 & 4 & 66 & 16 & 4356 & 264 \\
\hline 22 & 4 & 60 & 16 & 3600 & 240 \\
\hline 23 & 4 & 63 & 16 & 3969 & 252 \\
\hline 24 & 4 & 62 & 16 & 3844 & 248 \\
\hline 25 & 5 & 72 & 25 & 5184 & 360 \\
\hline 26 & 5 & 68 & 25 & 4624 & 340 \\
\hline 27 & 4 & 68 & 16 & 4624 & 272 \\
\hline 28 & 4 & 72 & 16 & 5184 & 288 \\
\hline 29 & 5 & 75 & 25 & 5625 & 375 \\
\hline 30 & 5 & 75 & 25 & 5625 & 375 \\
\hline 31 & 4 & 66 & 16 & 4356 & 264 \\
\hline 32 & 5 & 71 & 25 & 5041 & 355 \\
\hline 33 & 5 & 72 & 25 & 5184 & 360 \\
\hline 34 & 5 & 72 & 25 & 5184 & 360 \\
\hline 35 & 5 & 73 & 25 & 5329 & 365 \\
\hline 36 & 5 & 68 & 25 & 4624 & 340 \\
\hline 37 & 5 & 73 & 25 & 5329 & 365 \\
\hline 38 & 4 & 73 & 16 & 5329 & 292 \\
\hline 39 & 4 & 73 & 16 & 5329 & 292 \\
\hline 40 & 4 & 73 & 16 & 5329 & 292 \\
\hline 41 & 4 & 63 & 16 & 3969 & 252 \\
\hline 42 & 5 & 74 & 25 & 5476 & 370 \\
\hline 43 & 5 & 73 & 25 & 5329 & 365 \\
\hline 44 & 5 & 73 & 25 & 5329 & 365 \\
\hline 45 & 5 & 74 & 25 & 5476 & 370 \\
\hline 46 & 4 & 60 & 16 & 3600 & 240 \\
\hline 47 & 4 & 60 & 16 & 3600 & 240 \\
\hline 48 & 4 & 63 & 16 & 3969 & 252 \\
\hline 49 & 4 & 68 & 16 & 4624 & 272 \\
\hline 50 & 4 & 65 & 16 & 4225 & 260 \\
\hline 51 & 5 & 72 & 25 & 5184 & 360 \\
\hline 52 & 5 & 75 & 25 & 5625 & 375 \\
\hline 53 & 5 & 69 & 25 & 4761 & 345 \\
\hline 54 & 4 & 60 & 16 & 3600 & 240 \\
\hline 55 & 5 & 75 & 25 & 5625 & 375 \\
\hline Jumlah & 241 & 3676 & 1073 & 248006 & 16241 \\
\hline
\end{tabular}




$$
\begin{aligned}
r_{x y} & =\frac{n\left(\sum X Y\right)-\left(\sum X\right)\left(\sum Y\right)}{\sqrt{\left[n\left(\sum X^{2}\right)-\left(\sum X\right)^{2} \mid n\left(\sum Y^{2}\right)-\left(\sum Y\right)^{2}\right]}} \\
r x y & =\frac{55(16241)-(241)(3676)}{\sqrt{\left[55(1073)-(241)^{2}\right]\left[55(248006)-(3676)^{2}\right]}} \\
r x y & =\frac{893255-885916}{\sqrt{[(59015)-(58081)][(13640330)-(13512976)]}} \\
r x y & =\frac{7339}{\sqrt{(934)(127354)}} \\
r x y & =\frac{7339}{10906,36} \\
r x y & =0,673
\end{aligned}
$$

Keterangan : maka $\mathrm{r}_{\text {hitung }}>\mathrm{r}_{\text {tabel }}$ atau 0,673 > 0,266 dengan ketentuan $\alpha=5 \%$ dengan besar $r_{\text {tabel }}$ $=0,266$ maka varian butir item pernyataan no. 1 variabel kinerja $(\mathrm{Y})$ dapat dikatan valid.

\section{Uji Reliabilitas}

\section{Hasil Uji Reliabilitas Variabel X (Kompenasasi)}

Uji Reliabilitas suatu penelitian yang diukur sejauh mana hasil pengukuran dapat dipercaya. Menggunakan rumus Alpa Cronbach instrument dinyatakan dapat diandalkan ketika nilai alpha mendekati 1.

Temukan varian item dari data Variabel X diketahui :

$$
\begin{aligned}
\sum \mathrm{xi}^{2} & =1249 \\
\left(\sum \mathrm{xi}\right)^{2} & =(261)^{2} \\
\mathrm{n} & =55 ; \text { jumlah responden }
\end{aligned}
$$

Varian butir dihitung dengan memasukkan data tersebut ke dalam persamaan:

$S i^{2}=\frac{\sum \mathrm{xi}^{2}-\frac{\left(\sum \mathrm{x}\right)^{2}}{\mathrm{n}}}{\mathrm{n}}$

$S i^{2}=\frac{1249-\frac{(261)^{2}}{55}}{55}$

$S i^{2}=0,190$.

Hasil perhitungan menunjukkan bahwa nilai varians item untuk pernyataan nomor 1 adalah 0,190 . Dengan fase perhitungan yang sama, nilai item nomor 2 ke nomor 15 . Nilai total varians item untuk 15 item deklarasi dalam kuesioner Variable X adalah 5.170.

\begin{tabular}{|c|c|}
\hline \multicolumn{2}{|c|}{ Tabel 11. Nilai Varian Butir Variabel X } \\
\hline Pernyataan & Varian \\
\hline 1 & 0,190 \\
\hline 2 & 0,220 \\
\hline 3 & 0,246 \\
\hline 4 & 0,488 \\
\hline 5 & 0,488 \\
\hline 6 & 0,491 \\
\hline 7 & 0,349 \\
\hline 8 & 0,352 \\
\hline 9 & 0,286 \\
\hline 10 & 0,573 \\
\hline 11 & 0,323 \\
\hline 12 & 0,286 \\
\hline 13 & 0,358 \\
\hline 14 & 0,236 \\
\hline 15 & 0,284 \\
\hline $\mathbf{s i}$ & $\mathbf{5 , 1 7 0}$ \\
\hline & \\
\hline & Sumber: Data yang Diolah \\
\hline
\end{tabular}

Mencari varian total menurut data Variabel $\mathrm{X}$, diketahui :

$$
\begin{aligned}
\sum \mathrm{yt}^{2} & =245261 \\
\left(\sum \mathrm{yt}\right)^{2} & =(3659)^{2} \\
\mathrm{n} & =55
\end{aligned}
$$

Varian total dihitung dengan memasukkan data tersebut ke dalam persamaan:

$$
\begin{aligned}
S t^{2} & =\frac{\sum y \mathrm{t}^{2}-\frac{\left(\sum y \mathrm{t}\right)^{2}}{R}}{n} \\
S t^{2} & =\frac{245261-\frac{(3659)^{2}}{55}}{55} \\
S t^{2} & =33,413
\end{aligned}
$$

\section{Mencari nilai reliabel hitung}

Dari hasil perhitungan nilai varian di atas, selanjutnya dihitung nilai reliabilitas kuesioner Variabel X, sebagai berikut:

$\mathrm{k} \quad=15$; jumlah item pernyataan

$\Sigma \mathrm{Si}^{2}=5,170$

$\mathrm{St}^{2}=33,413$

Nilai reliabilitas kuesioner Variabel X, diperoleh dengan memasukkan data tersebut ke dalam persamaan. 
$r_{\iota}=\left(\frac{k}{k-1}\right)\left(1-\frac{\sum S i^{2}}{S t^{2}}\right)$

$r_{u}=\left(\frac{15}{15-1}\right)\left(1-\frac{5,170}{33,413}\right)$

$r_{u}=\frac{15}{14}(1-0,155)$

$r_{11}=\frac{15}{14}(0.845)$

$r_{u}=0,906$

Hasil perhitungan menunjukkan bahwa nilai $\mathrm{r}_{\text {hitung }}(0,906)>\mathrm{r}_{\text {tabel }}(0,266)$ dengan kondisi $\alpha=$ $5 \%$ sehingga semua item dalam kuesioner untuk Variabel X dinyatakan "reliabel".

\section{Uji Reliabilitas Variabel Y (Kinerja Kerja)}

Uji Reliabilitas suatu penelitian yang diukur sejauh mana hasil pengukuran dapat dipercaya. Menggunakan rumus Alpha Cronbach, instrumen dinyatakan dapat diandalkan ketika nilai alfa mendekati 1 .

Mencari varian butir

Dari data Variabel Y diketahui :

$$
\begin{aligned}
\sum x i^{2} & =1073 \\
\left(\sum x \mathrm{i}\right)^{2} & =(241)^{2} \\
\mathrm{n} & =55
\end{aligned}
$$

Varian butir dihitung dengan memasukkan data tersebut ke dalam persamaan :

$S i^{2}=\frac{\sum \mathrm{xi}^{2}-\frac{\left(\sum \mathrm{x}\right)^{2}}{\mathrm{n}}}{\mathrm{n}}$

$S i^{2}=\frac{1073-\frac{(241)^{2}}{55}}{55}$

$S i^{2}=0,309$

Hasil perhitungan menunjukkan nilai varian butir untuk pernyataan nomor 1 adalah 0,309. Dengan tahapan perhitungan yang sama, diperoleh nilai varian butir nomor 2 sampai dengan nomor 15. Jumlah nilai varian butir keseluruhan untuk 15 butir pernyataan pada kuesioner Variabel $Y$ adalah 5,279.

\begin{tabular}{|c|c|}
\hline \multicolumn{2}{|c|}{ Tabel 12. Nilai Varian Butir Variabel Y } \\
\hline Pernyataan & Varian \\
\hline 1 & 0.309 \\
\hline 2 & 0.527 \\
\hline 3 & 0.395 \\
\hline
\end{tabular}

\begin{tabular}{|c|c|}
\hline 4 & 0,286 \\
\hline 5 & 0,352 \\
\hline 6 & 0,323 \\
\hline 7 & 0,286 \\
\hline 8 & 0,431 \\
\hline 9 & 0,366 \\
\hline 10 & 0,286 \\
\hline 11 & 0,393 \\
\hline 12 & 0,395 \\
\hline 13 & 0,321 \\
\hline 14 & 0,323 \\
\hline 15 & 0,286 \\
\hline Esi & $\mathbf{5 . 2 7 9}$ \\
\hline & Sumber: Datayng Diolah \\
\hline
\end{tabular}

Mencari varian total

Berdasarkan data Variabel Y, diketahui :

$$
\begin{aligned}
\sum \mathrm{yt}^{2} & =248006 \\
(\text { (yt })^{2} & =(3676)^{2} \\
\mathrm{n} & =55
\end{aligned}
$$

Varian total dihitung dengan memasukkan data tersebut ke dalam persamaan :

$$
\begin{aligned}
S t^{2} & =\frac{\sum y \mathrm{t}^{2}-\frac{(\Sigma y \mathrm{t})^{2}}{n}}{n} \\
S t^{2} & =\frac{248006-\frac{(3676)^{2}}{55}}{55} \\
S t^{2} & =42,101
\end{aligned}
$$

\section{Mencari nilai reliabel hitung}

Dari hasil perhitungan nilai varian di atas, selanjutnya dihitung nilai reliabilitas kuesioner Variabel Y, sebagai berikut :

$\mathrm{k} \quad=15$; jumlah item pernyataan

$\Sigma \mathrm{Si}^{2}=5,729$

$\mathrm{St}^{2}=42,101$

Nilai reliabilitas kuesioner Variabel Y, diperoleh dengan memasukkan data tersebut ke dalam persamaan :

$$
\begin{aligned}
& r_{11}=\left(\frac{k}{k-1}\right)\left(1-\frac{\sum S i^{2}}{S t^{2}}\right) \\
& r_{11}=\left(\frac{15}{15-1}\right)\left(1-\frac{5,729}{42,101}\right) \\
& r_{11}=\frac{15}{14}(1-0,136) \\
& r_{11}=\frac{15}{14}(0,864) \\
& r_{11}=0,926
\end{aligned}
$$


Hasil perhitungan menunjukkan bahwa nilai $\mathrm{r}_{\text {hitung }}(0,926)>\mathrm{r}_{\text {tabel }}(0,266)$ dengan ketentuan $\alpha$ $=5 \%$ sehingga seluruh butir pernyataan dalam kuesioner untuk Variabel Y dinyatakan "reliabel".

\section{Analisis Korelasi}

Untuk mengetahui ada atau tidaknya pengaruh kompensasi $(\mathrm{X})$ terhadap kinerja karyawan (Y) dapat dihitung dengan koefisien korelasi dan tabel analisa sebagai berikut :

\begin{tabular}{|c|c|c|c|c|c|}
\hline \multicolumn{6}{|c|}{$\begin{array}{l}\text { Tabel 13. Pengaruh Kompensasi Terhadap Kinerja Karyawan } \\
\text { Pada PT. Gratia Prima Indonesia }\end{array}$} \\
\hline No & $x$ & $Y$ & $x^{2}$ & $Y^{2}$ & $X Y$ \\
\hline 1 & 72 & 73 & 5184 & 5329 & 5256 \\
\hline 2 & 73 & 73 & 5329 & 5329 & 5329 \\
\hline 3 & 73 & 72 & 5329 & 5184 & 5256 \\
\hline 4 & 56 & 59 & 3136 & 3481 & 3304 \\
\hline 5 & 60 & 67 & 3600 & 4489 & 4020 \\
\hline 6 & 59 & 56 & 3481 & 3136 & 3304 \\
\hline 7 & 68 & 65 & 4624 & 4225 & 4420 \\
\hline 8 & 62 & 62 & 3844 & 3844 & 3844 \\
\hline 9 & 64 & 63 & 4096 & 3969 & 4032 \\
\hline 10 & 64 & 62 & 4096 & 3844 & 3968 \\
\hline 11 & 60 & 58 & 3600 & 3364 & 3480 \\
\hline 12 & 75 & 60 & 5625 & 3600 & 4500 \\
\hline 13 & 53 & 46 & 2809 & 2116 & 2438 \\
\hline 14 & 60 & 60 & 3600 & 3600 & 3600 \\
\hline 15 & 69 & 65 & 4761 & 4225 & 4485 \\
\hline 16 & 61 & 62 & 3721 & 3844 & 3782 \\
\hline 17 & 57 & 56 & 3249 & 3136 & 3192 \\
\hline 18 & 68 & 66 & 4624 & 4356 & 4488 \\
\hline 19 & 57 & 57 & 3249 & 3249 & 3249 \\
\hline 20 & 74 & 75 & 5476 & 5625 & 5550 \\
\hline 21 & 65 & 66 & 4225 & 4356 & 4290 \\
\hline 22 & 61 & 60 & 3721 & 3600 & 3660 \\
\hline 23 & 64 & 63 & 4096 & 3969 & 4032 \\
\hline 24 & 60 & 62 & 3600 & 3844 & 3720 \\
\hline 25 & 66 & 72 & 4356 & 5184 & 4752 \\
\hline 26 & 68 & 68 & 4624 & 4624 & 4624 \\
\hline 27 & 66 & 68 & 4356 & 4624 & 4488 \\
\hline 28 & 75 & 72 & 5625 & 5184 & 5400 \\
\hline 29 & 75 & 75 & 5625 & 5625 & 5625 \\
\hline 30 & 75 & 75 & 5625 & 5625 & 5625 \\
\hline 31 & 64 & 66 & 4096 & 4356 & 4224 \\
\hline 32 & 75 & 71 & 5625 & 5041 & 5325 \\
\hline 33 & 69 & 72 & 4761 & 5184 & 4968 \\
\hline 34 & 69 & 72 & 4761 & 5184 & 4968 \\
\hline 35 & 69 & 73 & 4761 & 5329 & 5037 \\
\hline 36 & 71 & 68 & 5041 & 4624 & 4828 \\
\hline 37 & 72 & 73 & 5184 & 5329 & 5256 \\
\hline 38 & 72 & 73 & 5184 & 5329 & 5256 \\
\hline
\end{tabular}

\begin{tabular}{|c|c|c|c|c|c|}
\hline 39 & 69 & 73 & 4761 & 5329 & 5037 \\
\hline 40 & 65 & 73 & 4225 & 5329 & 4745 \\
\hline 41 & 62 & 63 & 3844 & 3969 & 3906 \\
\hline 42 & 71 & 74 & 5041 & 5476 & 5254 \\
\hline 43 & 72 & 73 & 5184 & 5329 & 5256 \\
\hline 44 & 72 & 73 & 5184 & 5329 & 5256 \\
\hline 45 & 71 & 74 & 5041 & 5476 & 5254 \\
\hline 46 & 61 & 60 & 3721 & 3600 & 3660 \\
\hline 47 & 61 & 60 & 3721 & 3600 & 3660 \\
\hline 48 & 64 & 63 & 4096 & 3969 & 4032 \\
\hline 49 & 69 & 68 & 4761 & 4624 & 4692 \\
\hline 50 & 65 & 65 & 4225 & 4225 & 4225 \\
\hline 51 & 73 & 72 & 5329 & 5184 & 5256 \\
\hline 52 & 73 & 75 & 5329 & 5625 & 5475 \\
\hline 53 & 60 & 69 & 3600 & 4761 & 4140 \\
\hline 54 & 60 & 60 & 3600 & 3600 & 3600 \\
\hline 55 & 70 & 75 & 4900 & 5625 & 5250 \\
\hline Jumlah & 3659 & 3676 & 245261 & 248006 & 246273 \\
\hline & & & & \multicolumn{2}{|c|}{ Sumber : Data yang diolah } \\
\hline
\end{tabular}

$$
\begin{aligned}
& r_{x y}=\frac{n\left(\sum X Y\right)-\left(\sum X\right)\left(\sum Y\right)}{\sqrt{\left[n\left(\sum X^{2}\right)-\left(\sum X\right)^{2} \mid n\left(\sum Y^{2}\right)-\left(\sum Y\right)^{2}\right]}} \\
& r x y=\frac{55(246273)-(3659)(3676)}{\sqrt{\left[55(245261)-(3659)^{2}\right]\left[55(248006)-(3676)^{2}\right]}} \\
& r x y=\frac{13545015-13450484}{\sqrt{[(13489355)-(13388281)][(13640330)-(13512976)]}} \\
& r x y=\frac{94531}{\sqrt{(101074)(127354)}} \\
& r x y=\frac{94531}{\sqrt{12872178196}} \\
& r x y=\frac{94531}{113455,62} \\
& r x y=0,833
\end{aligned}
$$

Berdasarkan perhitungan diatas diperoleh nilai koefisien korelasi (r) sebesar 0,833. Seperti yang tertera intervensi nilai korelasi $r$, jika $r>$ 0 maka terjadi hubungan yang positif. Apabila interval koefisien korelasi berada pada nilai 0,8001,000 maka hal itu memberikan indikasi bahwa kompensasi (X) memiliki pengaruh yang kuat terhadap kinerja (Y) karyawan pada PT.Gratia Prima Indonesia.

Tabel 14. Pedoman untuk Membuktikan Interprestasi Koefisien Korelasi

\begin{tabular}{|c|c|}
\hline Interval koefisien & Tingkat hubungan \\
$0,000-0,199$ & Hubungan sangat rendah \\
\hline $0,200-0,399$ & Hubungan rendah \\
\hline $0,400-0,599$ & Hubungan sedang \\
\hline $0,600-0,799$ & Hubungan kuat \\
\hline $0,800-1,000$ & Hubungan sangat kuat \\
\hline & Sumber: Sugiyono (2004: 194) \\
\hline
\end{tabular}




\section{Koefisien Determinasi}

Koefisien Determinasi dilakukan untuk mengetahui seberapa besar kontribusi variabel $\mathrm{X}$ terhadap variabel $\mathrm{Y}$, maka selanjutnya digunakan rumus sebagai berikut :

$$
\begin{aligned}
\mathrm{KD} & =\mathrm{r}^{2} \times 100 \% \\
& =(0,833)^{2} \times 100 \% \\
& =0,6939 \times 100 \% \\
& =69,39 \%
\end{aligned}
$$

Dari perhitungan koefisien Determinasi (Kd) diatas, maka diperoleh nilai sebesar 69,39. Hal ini menunjukkan bahwa kontribusi kompensasi dalam upaya meningkatkan kinerja karyawan cukup besar karena berada diatas 50\% yaitu sebesar 69,39\%, sedangkan selebihnya (100\%$69,39 \%$ ) sebesar $30,61 \%$ dipengaruhi oleh faktor lain seperti : lingkungan internal dan eksternal, fasilitas kerja, manajemen perusahan dan sebagainya.

\section{Hipotesis (Uji t)}

Data-data yang dihasilkan dari sebuah hasil analisis variabel dependen dan variabel independen perlu diuji untuk mengetahui hubungan keduanya. Untuk menguji pengaruh variabel independen terhadap variabel dependen digunakan uji t. Pengujian melalui uji $t$ adalah membandingkan $\mathrm{t}_{\text {hitung }}$ dengan $\mathrm{t}_{\text {tabel }}$ pada derajat signifikan $95 \% \alpha=5 \%$

Rumus :

$$
t=\frac{r \sqrt{n-2}}{\sqrt{1-r^{2}}}
$$

Di mana :

$$
\mathrm{r}=\text { Koefisien Korelasi }
$$

$\mathrm{n}=$ jumlah responden

$t_{\text {hitung }}=t_{\text {hitung }}$ yang selanjutnya dikonsultasikan dengan $t_{\text {tabel }}$

$$
\begin{aligned}
t_{\text {hitung }} & =\frac{r \sqrt{n-2}}{\sqrt{1-r^{2}}} \\
& =\frac{0,833 \sqrt{55-2}}{\sqrt{1-0,833^{2}}} \\
\mathrm{t} & =\frac{0,833 \sqrt{53}}{\sqrt{1-0,69}} \\
\mathrm{t} & =\frac{6,06}{0,56} \\
\mathrm{t} & =10,82 \\
t_{\text {hitung }} & =10,82 \\
t_{\text {tabel }} & =2,006
\end{aligned}
$$

Berdasarkan nilai $\mathrm{t}_{\text {hitung }}$ dan $\mathrm{t}_{\text {tabel }}$ masingmasing variabel independen dapat diketahui bahwa kompensasi berpengaruh terhadap kinerja karyawan dalam uji $\mathrm{t}$, didapat hasil $\mathrm{t}_{\text {hitung }}$ adalah 10,82 sedangkan untuk $\mathrm{t}_{\text {tabel }}$ didapat angka 2,006. Karena $\mathrm{t}_{\text {hitung }}>\mathrm{t}_{\text {tabel }}(10,82>2,006)$, maka $\mathrm{H}_{0}$ ditolak. Dengan kata lain hipotesis kedua $\left(\mathrm{H}_{\mathrm{a}}\right)$ diterima, kompensasi berpengaruh terhadap kinerja.

\section{SIMPULAN}

Berdasarkan hasil penjaringan informasi melalui penyebaran dua buah kuesioner yang berisi masing-masing 15 item pernyataan kepada 55 pegawai sebagai responden pada PT. Gratia Prima Indonesia serta analisis dan evaluasi terhadap data yang diperoleh, maka penulis dapat menyimpulkan beberapa hal, yaitu: Pemberian Kompensasi merupakan aspek penting yang dibutuhkan untuk meningkatkan kinerja pegawai. Hal ini terlihat dari hasil penelitian yang menunjukkan data kuesioner tentang pelaksanaan Kompensasi (Variabel X) yang menunjukkan jumlah responden menjawab sangat setuju (49,8\%), setuju (44,6\%), ragu-ragu/ netral (5\%), sedangkan yang menjawab tidak setuju $(0,5 \%)$, serta sangat tidak setuju $(0,1 \%)$. Melalui pengujian terhadap butir pernyataan no satu. $\mathrm{r}_{\text {hitung }}>\mathrm{r}_{\text {tabel }}$ atau 0,517 $>0,266$ dengan ketentuan $\alpha=5 \%$ dengan besar $r_{\text {tabel }}=0,266$ maka varian butir item pernyataan no.1 variabel kompensasi (X) dapat dikatan valid. Serta hasil perhitungan menunjukkan bahwa nilai $\mathrm{r}_{\text {hitung }}$ $(0,906)>r_{\text {tabel }}(0,266)$ dengan ketentuan $\alpha=$ 5\% sehingga seluruh butir pernyataan dalam kuesioner untuk Variabel X dinyatakan "reliabel.

Kinerja Pegawai sudah baik, terlihat dari data kuesioner yang menunjukkan produktivitas sebagai salah satu parameter kinerja (Variabel Y) memiliki persentase tinggi, yaitu jumlah responden menjawab sangat setuju (50,1\%), setuju (46,3\%), ragu-ragu/netral (2,8\%), sedangkan yang menjawab tidak setuju $(0,8 \%)$, serta sangat tidak setuju (0\%). Setelah dilakukan pengujian validitas butir pernyataan no satu di dapatkan. $\mathrm{r}_{\text {hitung }}>$ rtabel atau 0,673 >0,266 dengan ketentuan $\alpha=5 \%$ dengan besar $r_{\text {tabel }}=0,266$ maka varian butir item pernyataan no.1 variabel kinerja $(\mathrm{Y})$ 
dapat dikatan valid.Dan juga Hasil perhitungan menunjukkan bahwa nilai $r_{\text {hitung }}(0,926)>r_{\text {tabel }}$ $(0,266)$ dengan ketentuan $\alpha=5 \%$ sehingga seluruh butir pernyataan dalam kuesioner untuk Variabel Y dinyatakan "reliabel".

Hasil penelitian menunjukkan adanya korelasi yang signifikan antara Pelaksanaan Kompensasi terhadap Kinerja karyawan. Hal ini ditunjukkan dengan nilai parameter korelasi dan koefisien determinasi diantara dua variabel tersebut. Korelasi (rxy), Hasil analisis dan evaluasi menunjukkan adanya korelasi yang kuat antara kompensasi terhadap kinerja pegawai yang ditunjukkan oleh nilai $\mathrm{r}_{\text {hitung }}$ sebesar 0,833 . Nilai tersebut berada dalam rentang nilai korelasi sangat kuat, yaitu 0,8 - 1,00. Hal ini dapat didefinisikan bahwa semakin baik tingkat pelaksanaan kompensasi akan semakin baik pula kinerja pegawai. Koefisien Determinasi (R2) menunjukkan pengaruh kompensasi terhadap kinerja karyawan sebesar 69,39\%, sisanya 30,61\% dipengaruhi oleh faktor lain seperti : limgkungan internal dan eksternal, fasilitas kerja, manajemen perusahan dan sebagainya. Uji Signifikansi Hipotesis $(\mathrm{t})$ menunjukkan nilai $\mathrm{t}_{\text {hitung }}(10,82)$ lebih besar daripada $t_{\text {tabel }}(2,006)$ sehingga dapat disimpulkan bahwa hipotesis pertama $\left(\mathrm{H}_{0}\right)$ yang menyatakan tidak ada hubungan antara "Variabel X" dengan "Variabel Y" DITOLAK. Dengan kata lain, hipotesis kedua $\left(\mathrm{H}_{\mathrm{a}}\right)$ yang menyatakan bahwa terdapat hubungan antara "Variabel X" dengan "Variabel Y" DITERIMA.

\section{PENGHARGAAN}

Puji syukur saya sampaikan kehadirat Allah SWT, yang telah memberikan rahmat dan kehendak-Nya sehingga terselesaikan penelitian ini. Juga, rasa terima kasih ini juga saya sampaikan kepada PT Gratia Prima, yang telah mengisi kuesioner yang saya berikan sehingga terwujudlah hasil penelitian ini.

\section{DAFTAR PUSTAKA}

Basri, A. F. M., \& Rivai, V. (2005). Perfomance Appraisal. Jakarta: PT Raja Grafindo Persada. Bungin, B. (2009). Penelitian Kualitatif. Jakarta:
Kencana.

Bungin, B. (2006). Sosiologi Komunikasi. Jakarta: Kencana.

Dessler, G. (2004). Manajemen Sumber Daya Manusia, Edisi 9, Jilid 1. Jakarta: Kelompok Gramedia.

Hasibuan, S.P. M. (2009). Manajemen Sumber Daya Manusia. Edisi Revisi. Jakarta: Bumi Aksara.

Mangkunegara, A. P.(2007). Evaluasi Kinerja Sumber Daya Manusia, Cetakan Ketiga. Bandung: Penerbit PT. Refika Aditama.

Mulyadi. (2001) Akuntansi Manajemen: Konsep, Manfaat dan Rekayasa, Edisi Ketiga. Jakarta: Salemba Empat.

Nawawi, H. (2001). Manajemen Sumber Daya Manusia. Jakarta : Ghalia Indonesia.

Nawawi, H. (2003), Manaiemen Sumber Daya Manusia (Hukum Bisrtis Yang Kompetitif. Yogyakarta: Gadjah Mada University Press.

Rivai, V. (2006). Manajemen Sumber Daya Manusia untuk Perusahaan: Dari Teori ke Praktek, Edisi Pertama, Cetakan Ketiga. Jakarta: Penerbit PT. Grafindo Persada.

Sekaran, U. (2007). Research Methods For Business (Cetakan I edisi 4). Jakarta: Salemba Empat. Simamora, H.(2004). Manajemen Sumber Daya Manusia, Edisi Ketiga, Cetakan Pertama. Yogyakarta: Bagian Penerbitan STIE YKPN. Soetjipto, Budi, W., et.al. (2005). Paradigma Baru-Manajemen Sumber Daya Manusia, Yogyakarta: Amara Books.

Sugiyono, D. (2008). Metode Penelitian Kuantitatif Kualitatif dan R\&D. Bandung: Alfabeta.

Sugiyono, (2013). Metode Penelitian manajemen. Cetakan kesatu. Bandung: Alfabeta.

Umar, H. (2002). Metode Riset Bisnis. Jakarta: PT. Gramedia Pustaka Utama. 